\title{
Western Medicine in French Pondichéry (1690-1954)
}

\author{
Ramya Raman* and Anantanarayanan Raman**
}

(Received 20 February, 2017)

\begin{abstract}
The European practice of health management in the French territories across the world was first established in Pondichéry, India. From Pondichéry, health management practice gradually spread to other French colonies within India and elsewhere. A western-medicine based hospital managed by the Jesuits existed in the 1690s in Pondichéry. L'Hôpital Militaire - a formal and larger establishment situated close to the French East-India Company Garden - came up close to l'Église Sacré Cour de Jésus in 1738. From 1742 a hospital functioned in Ôzhukarai, a village six km north of Pondichéry’s central business district, managed by the missionaries of the Order of Friars Minor Capuchin, which included 10 rooms to help the sick. This Capuchins-managed hospital was refurbished in the mid-1760s. L'Hôpital Pondichéry (the Pondichéry Hospital) came up in 1853. The French Government at Pondichéry established le Ministerè de la Santé (Department of Health) as its administrative component in 1863. A dedicated facility to train pharmacists and midwives started in 1905 and 1912, respectively. Radiology, surgical, and maternity wards were established in 1913, 1926, and 1937, respectively. After 1961, this facility was rebuilt as a contemporary hospital and the medical college was located to the northwest of the town in the Jawaharlal Institute of Post-graduate Medical Education and Research (JIPMER) campus. The first formal medical school among all the French colonies was established in Pondichéry aligning with colonization by the French in the $19^{\text {th }}$ century. L'École de Médicine de Pondichéry (l'ÉMP) was launched during the leadership of Napoléon Bontemps (Governor-General of French-India Territories) in 1863, under the superintendence of Jean Baptiste Jules Beaujean. L'ÉMP trained mostly Indians enabling them to become midwives, health inspectors, and vaccinators, besides doctors. During early days, the student number in medicine never exceeded six and they were trained for three years. In later years the number of years of training was modified to five, after which students received the title Docteur Médecin. Medical curriculum at l'ÉMP corresponded to that offered in France and was governed by the rules of Bureau de Santé Français in Paris. A few of the early Indian graduates of l'ÉMP were Paramananda Mariadassou, Amala Mariadassou, and Marcelin Ponnupillai Tirouvanziam, who practiced medicine in Pondichéry and nearby Karaikãl, another French territory. The present paper also speaks of the attitude of French surgeons towards Indian traditional medical knowledge, the trailblazing discovery of the active principle vallãrine from a local plant Hydocotyle asiatica (vallãrai, Tamil) by Jules Lépine, a pharmacien attached to Pondichéry Health Service in the $19^{\text {th }}$ century, appointments of health officers in government service, and the establishment of para-medical and exploratory medical facilities viewed against similar features of Madras Medical Service.
\end{abstract}

Key words: Beaujean, Capuchins, France, Huillet, Jesuits, Lépine, L’École de Médicine de Pondichéry, Mariadassou, Nineteenth Century.

\section{INTRODUCTION}

French medical personnel were revolutionizing medicine in the $19^{\text {th }}$ century. For example, René Théophile Hyacinthe Laënnec
(1781-1826) conceptualized the stethoscope in 1816 and announced its science in 1819 (Portrait 1), Jean Baptiste Cruveilhier (1791-1874) contributed to an elegant understanding of 


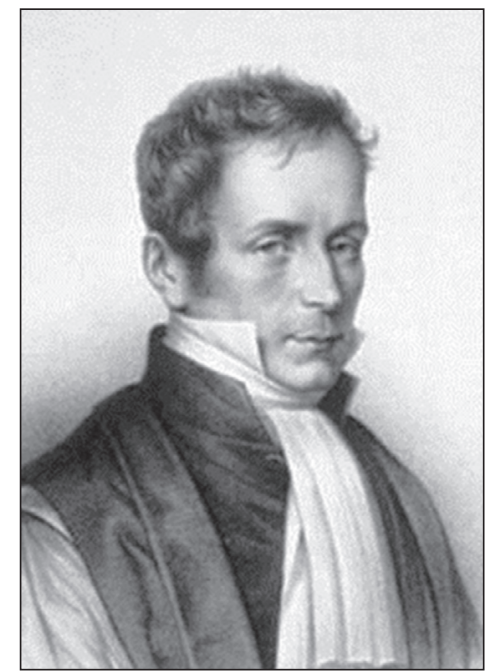

Portrait 1. Rene Théophile Laënnec

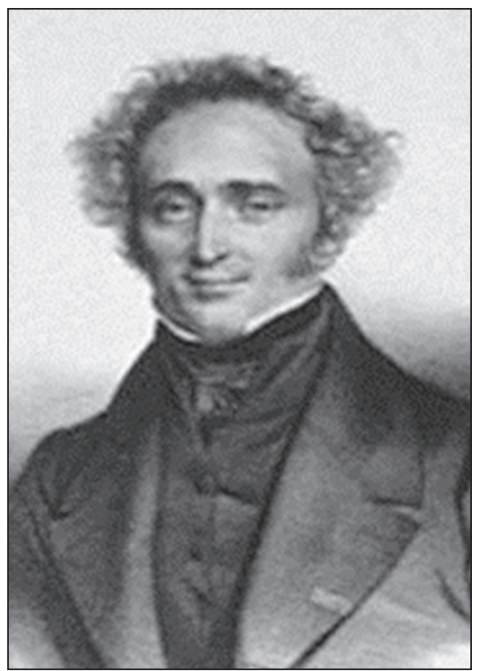

Portrait 2. Léon Jean Baptiste Cruveilhier

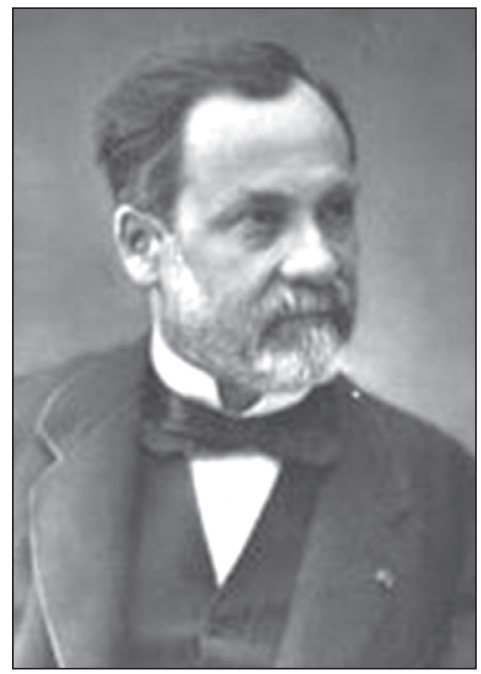

Portrait 3. Louis Pasteur pathological anatomy (Portrait 2), and the microbiological work of Louis Pasteur (18281895) (Portrait 3) established the microbial cause of infective diseases (Bernoulli, 1985).

One key reason for setting up healthmanagement facilities in its colonies by France in the $17^{\text {th }}$ and $18^{\text {th }}$ centuries was to offer some medical care to sailors belonging to the French military, most of who generally developed scurvy after 4-6 months of sailing. Le Service de Santé de la Marine (the Naval Health Service) established by Louis the XIV in Paris was additionally charged with the responsibility of management of the health of its military personnel in French territories (Chippaux, 1980). That the European practice of health management in French territories was first established in Pondichéry $\left(11^{\circ} 552 \mathrm{~N}, 79^{\circ} 472 \mathrm{E}\right)$ is indeed notable. From Pondichéry, this health management practice gradually spread to other French colonies throughout the world, starting from Madagascar (Aubry and Gaüzère, 2016).

\section{Hospitals}

A western-medicine based 'hospital' managed by the Jesuits existed in the 1690s in the eastern-most segment of the then Pondichéry (Stephen, 2008). French Jesuits, who escaped from Siam (Love, 1994), settled in Madurai (9 $92 \mathrm{~N}$; $78^{\circ} 12 \mathrm{E}$ ), the centre of Jesuit activity in the Tamil region since the early decades of the $17^{\text {th }}$ century. However the first Superior of the Jesuits in India, Guy Tachard, S.J., (1651-1712), a mathematician by training and who studied Astronomy, preferred to settle in Pondichéry. Tachard will be remembered for his fascinating narrative of his life-experiences in Siam (Thailand): le Voyage de Siam des Pères Jésuites, Envoyés par le Roi aux Indes et à la Chine: Avec Leurs Observations Astronomiques, et leurs Remarques de Physique, de Géographie, d'Hydrographie et d'Histoire (Paris: Arnould Seneuze, 1686) [A Relation of the Voyage to Siam: Performed by Six Jesuits, Sent by the King of France, to the Indies and China, in the Year, 1685: with their Astronomical Observations, and their Remarks of Natural Philosophy, Geography, Hydrography, and History, London: J. Robinson \& A. Churchil, 1688]. In Pondichéry, Tachard opened the first 'school', where he taught navigation and mathematics to children of French and Portuguese-Indian descent. Tachard also established a hospital that responded mostly to 
European needs. A vague source indicates that this hospital also treated the Maratta and Moghul soldiers, who were wounded in battles that occurred near Pondicherry (Kaeppelin, 1908). François Martin, Chief Administrator, with the title 'Governor-General of French India' (1699-1706, in office), re-built this facility, shifting it closer to sea in 1699. A third facility, l'Hôpital Militaire (Military Hospital) - a more formal and larger establishment situated close to the French EastIndia Company Garden (Raman 2014) - came up across the Church of Sacred Heart of Jesus (Église Sacré Cour de Jésus, 'Basilica' presently) in 1738. The Ursuline Sisters treated the wounded soldiers ran it (sic. l'Hôpital Militaire) in Pondichéry (Huillet, 1867a). The takeover of l'Hôpital Militaire administration by the Ursuline Sisters should have occurred after 1755. L'Hôpital Militaire was equipped to treat sailors of the French army and the soldiers who minded army stores. Access to the people of Indian descent was denied here until the mid-decades of the $19^{\text {th }}$ century (Thomas 2002). A contradiction in detail occurs here. Ramaswamy (2009, p. 246) says:

\begin{abstract}
"The monastic order of the Ursuline Sisters arrived on their own initiative in 1755 at Pondicherry to spread the message of Christianity in South India. The nuns were stopped at the port itself and after an excruciating and humiliating wait for three months, were ordered by the Bishop to return by the same ship that had brought them to India."
\end{abstract}

A western-medicine based hospital functioned from 1742 in Ôzhukarai (Uzhavarkarai, Oulgarét, $11^{\circ} 96^{\prime} \mathrm{N}, 79^{\circ} 77^{\prime} \mathrm{E}$ ) a village six km north of Pondichéry's central business district. François Martin sold the parcel of land at Ôzhukarai to the missionaries of the Order of Friars Minor Capuchin (the Capuchins), who did not possess enough money to pay Martin. A few wealthy locals helped the Capuchins to buy the block of land, on which the Capuchins constructed their church. They also constructed their living quarters and a hospital with 10 rooms to help the sick. This hospital was refurbished in mid-1760s.

l'Hôpital Pondichéry (the Pondichéry Hospital) came up in 1853 (Massey, 2012). The French Government at Pondichéry established le Ministerè de la Santé (Department of Health) as its administrative component in 1863. A dedicated facility to train pharmacists and midwives started in 1905 and 1912, respectively. A radiology ward was established in 1913, a new surgical ward in 1926, and a maternity ward in 1937 (Bigot 1966). After the integration of Pondichéry with the Indian Republic, this was rebuilt as a modern hospital and the medical college was to the northwest of the town in JIPMER (Jawaharlal Institute of Postgraduate Medical Education and Research) campus. Health management in Pondichéry expanded in later years with the development of four hospitals, one prison-health service, one leprosarium, and 13 free clinics, servicing local residents, until Pondichéry's integration with India in 1961.

\section{The Medical School and its Pioneering Teachers}

The first formal medical school among all the French colonies was established in Pondichéry aligning with the expansion by the French in the $19^{\text {th }}$ century. L'École de Médicine de Pondichéry (l'ÉMP; the Medical School of Pondichéry) was launched during the leadership of Napoléon Joseph Louis Bontemps (Governor-General of French-India Territories) in 1863, under the superintendence of Naval Surgeon Jean Baptiste Jules Beaujean. Beaujean qualified for the Docteur Médecin title from the medical school of the

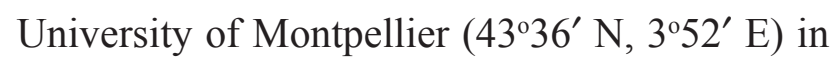
1856, writing a thesis entitled Quelques Observations Medicales sur une Campagne dans la Baltique (Some medical observations made during a Baltic military campaign) (Massey, 2007). Beaujean taught medicine and surgery at 
l'ÉMP. Surgeon Numa Huillet taught anatomy and minor surgical procedures. One Stanislas Godineau is indicated as another assistant to Beaujean at l'ÉMP, although no further details of either Godinaeu or his work are traceable, except that both Huillet and Godineau were designated 'First Class Surgeons'.

Huillet, in addition to serving as an assistant surgeon attached to le Ministerè de la Santé de Pondichéry, was interested in studying anthropology and human evolution from a biological, medical perspective (Huillet, 1867b). Considering reasonably well-sampled surveys of the French, Indians (treated generically as Hindus, which included native Muslims), people of
Franco-Indian and Indo-Portuguese roots, and the immigrant Créoles (from Africa and the West Indies), Huillet suggests that the Créole community was the best suited to live in Pondichéry given the nature of its climate. Huillet also seems to have had an interest in exploring the supposed ancient Indian practice of 'variolation', as alluded to in Dhanwantari's Yogaçintamani (Rose, 1863). About six decades earlier, one 'Calvi Virumbon' (read as Kalvi Virumpan: knowledge lover [seeker]? A pseudonym?) in a letter to the Madras Courier (published on 12 January 1819, Fig. 1) claimed that vaccination was known in ancient India while talking about the spasmodic cholera - an epidemic which was affecting the Madras population in the

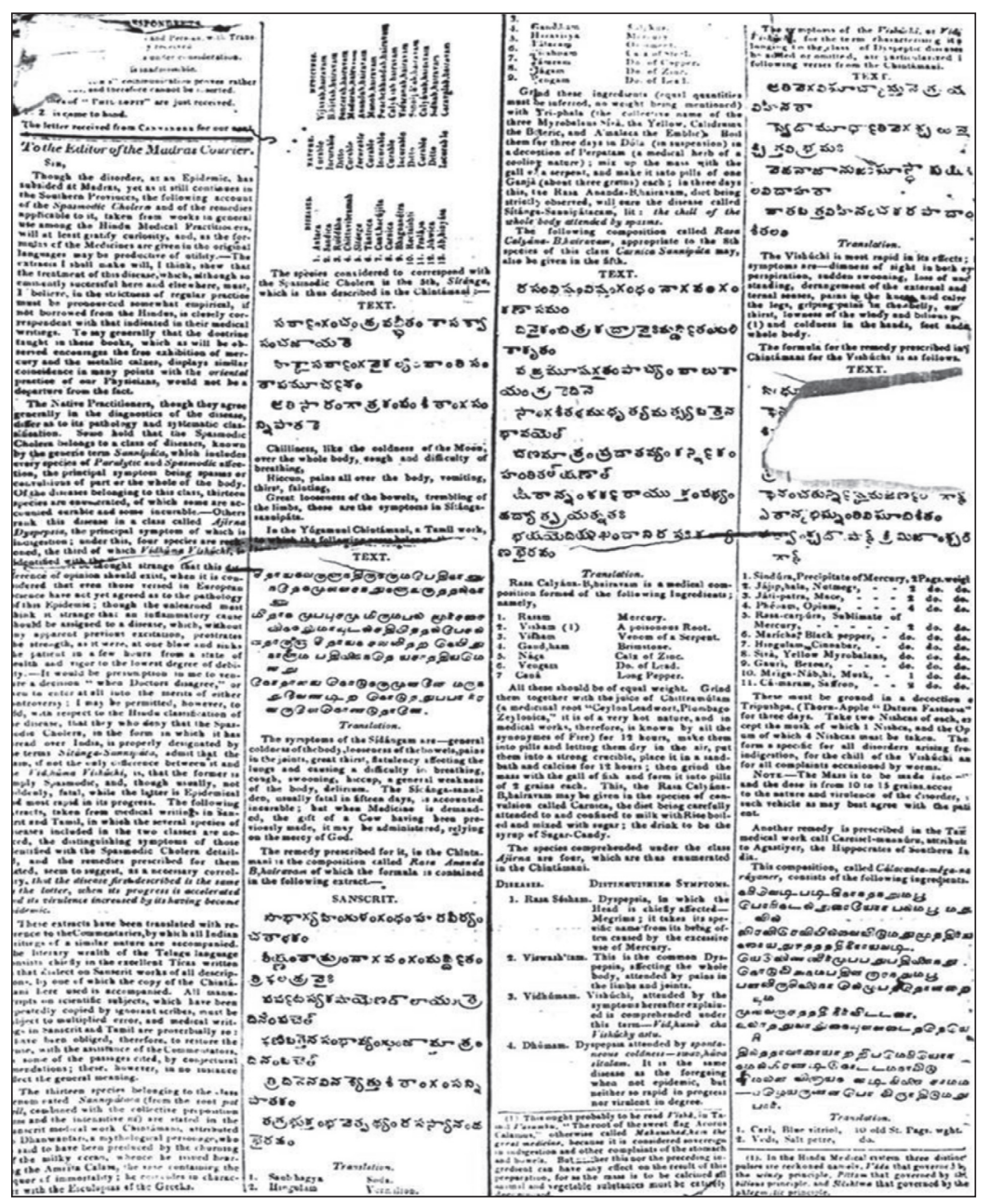

Fig. 1. Facsimile of the letter (first page only) of Calvi Virumbon of Madras written on variolation to the editor of Madras Courier (1809) 
1810s. Virumbon quotes from Yogaçintamani (edited by Harsakirti with Telugu commentary) and Yukimuni Çintamani, Kareiçal Munnuru (the latter attributed to Sage Agastiyã) that describe the concoctions useful against spasmodic cholera (Wujastyk, 2001). This letter of Virumbon created ripples in the world of medical science (Brimnes, 2004), including distant places such as Europe (Husson, 1822) and North America (Ducachet, 1822).

L'ÉMP trained mostly Indians in varied medical vocations enabling them to become doctors, midwives, health inspectors, and vaccinators. During early days, the student number in medicine never exceeded six and the students trained for three years. However, in later years, the numbers grew to 50. Students studied for five years to graduate as a trained doctor, receiving the title Docteur Médecin. Medical curriculum at 1'ÉMP corresponded to that offered in France and was governed by the rules of Bureau de Santé Français (the French Health Office) in Paris. Training of health inspectors ceased in 1892. From the 1890 s, only those who successfully completed 5-year medical training were licensed to practice. A few of the early Indian graduates of l'ÉMP were Paramananda Mariadassou, Amala Mariadassou, and Marcelin Ponnupillai Tirouvanziam, who practiced medicine in Pondichéry and nearby Karaikal, another French territory that remained under Pondichéry administration (Nallam, 2009).

Details of medical practice (e.g., forensic procedures, treatment of beriberi and cholera) followed by Beaujean and Huillet at l'ÉMP are available in le Dictionnaire Encyclopedique des Sciences Médicales (Dechambre et al. 18641889). Paramananda Mariadassou (read as Mariadãs) was the first Pondichérian to graduate from l'ÉMP. With the integration of Pondichéry with the Indian Republic in 1954, the school became the Pondichéry Medical College (Fig. 2), which, in recent times was renamed the Jawaharlal Institute of Postgraduate Medical Education \& Research (JIPMER) and moved to the outskirts of Pondichéry. l'ÉMP building today exists as the Legislative Assembly building of Pondichéry.

\section{Jules Lépine's Study of Hydrocotyle asiatica's Medicinal Relevance}

Jules Lépine, referred as an 'apothecary' (Anonymous, 1855) and a 'pharmacien' (by an unverifiable Internet source) attached to le Ministerè de la Santé de Pondichéry tested the efficacy of an Indian native herb Hydrocotyle

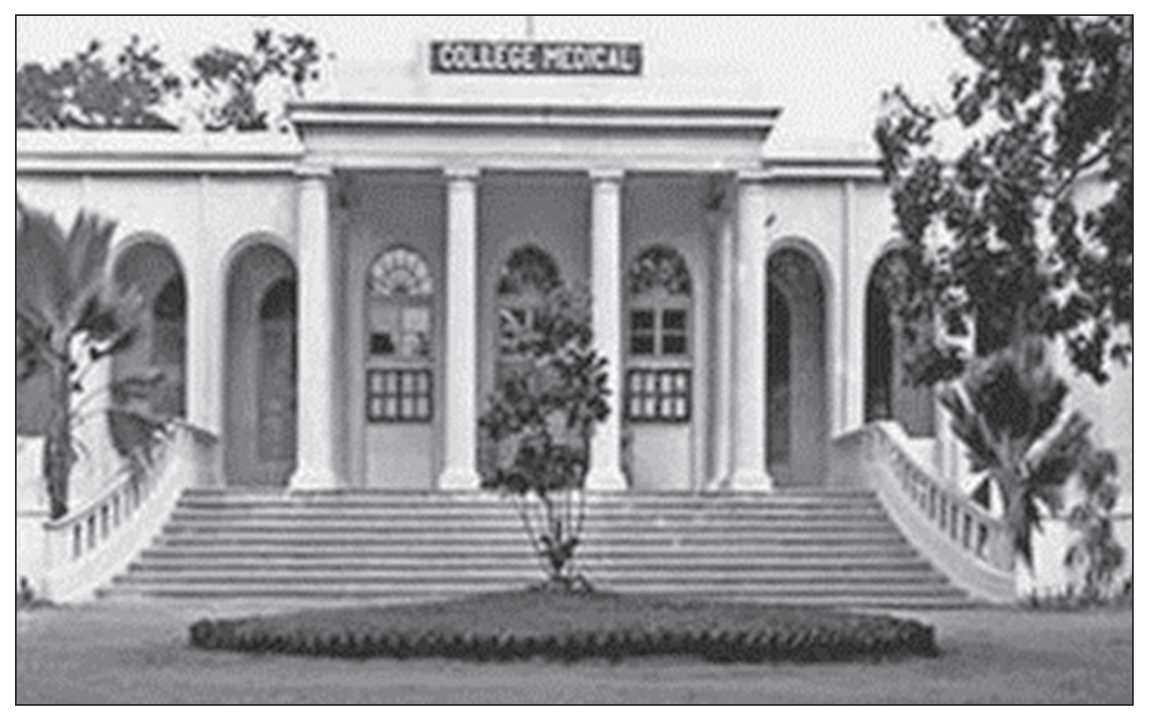

Fig. 2. Collége Medical de Pondichéry (until 1961). Today this building is refurbished and used as the Legislative Assembly of the State of Pondichéry. 
asiatica (Apiaceae, the present name: Centella asiatica) in the treatment of leprosy after exploring its chemistry in detail. Lépine found that the hydroalcoholic extracts obtained in vacuo were helpful in the management of not only leprosy, but also elephantiasis, rheumatism, syphilis, and herpetic infections (Lépine, 1855). He reported his exhaustive investigations on the chemistry of $H$. asiatica and identified the principal active compound as 'vallarine'. Subsequent work on vallarine by Leyel (1970) explains it as one having the odour and bitter persistent taste of the fresh plant, resin, some fatty aromatic body, gum, sugar, albuminous matter, salts, mostly alkaline sulphates, and tannin. Later work on $H$. asiatica indicates that it stimulates the autonomous nervous system, and high doses can bear a narcotic effect (Oliver-Bever, 1983). The section 'Formulae used in Government Pharmacies in Pondichéry' in Lépine's publication (1855, pages 23-26) is attention-provoking, since it explains how to prepare the powder, tisane, syrup, pomade, tincture, baths of $H$. asiatica in great detail. Lépine, in the same paper, describes the trials he made on using Hydrocotyle preparations (as above) on 80 patients in Pondichéry and in Madras Leper Asylum (Raman et al. 2012) by Alexander Hunter, a surgeon of the Madras Medical Service are also available. Alexander Hunter will be remembered for his contributions to the development of fine arts in Madras including photography. At the end of his article, Lépine says (1855, page. 27$)$ :

\footnotetext{
"We must observe that that French doctors have given this remedy in such large does, as to be obliged to interrupt the treatment; the English (sic. in Madras) have obtained excellent results by utilizing this medicine, in the dose from 75 centigrammes to one gramme of powder per day; it will consequently be necessary in using the hydroctyle, to diminish the doses as determined by him (sic. J. Lépine), which are calculated in accordance with the observations of the French doctors'.
}

Lépine's article (1855) referred here is extracted from the Chemist - A Monthly Journal of Chemical \& Physical Science, an English translation of the original French publication made in the July 1855 issue of the Journal de Pharmacie et de Chimie published by the Société de Pharmacie de Paris. Lépine was awarded a medal for this discovery at the Exposition International des Matières Premières (International Exhibition of Raw Materials) held at Besonçon (along the Doubs River, Eastern France) in 1860 (Bonnemann 2008). A useful description of the botany and pharmacognosy of $H$. javanica is available in Dymock (1885, pages 361-362), which also refers to Lépine's discovery of vallarine and trials of this plant extract in the Madras Leper Hospital by Alexander Hunter.

\section{Paramananda Mariadassou}

Paramananda Mariadassou (1870-1947) contributed significantly to medical science further to practicing as a surgeon in Karaikal (another French territory, c. $130 \mathrm{~km}$ south of Pondichéry, $\left.10^{\circ} 56^{\prime} \mathrm{N}, 79^{\circ} 50^{\prime} \mathrm{E}\right)$. For a detailed biographic note on Mariadassou, the reader is referred to Histoire de la Médecine de l'Inde Française by Venkataramaiah Nallam (2009). This book includes Mariadassou's photograph. He was attached to the Karaikal Hospital. He wrote Moeurs Médicales de l'Inde et leurs Rapports avec la Médecine Européenne (Medical ethics of India and their relationships with European medicine), Médecine Traditionnelle de I'Inde: Guideformulaire de Thérapeutique Ayulvedique (Traditional Medicine of India: Arurvedic Therapeutic Guide), and Médicine Traditionnelle de I'Inde: Histoire de la Médicine Hindoue (Traditional Medicine of India: Hindu Medical History). Albert Calmette (1863-1933), an acclaimed French physician, bacteriologist, immunologist, and a colleague of Louis Pasteur, refers to Mariadassou's treatment of snake bites in his Venoms, Venomous Animals, and Antivenomous Serum (Calmette, 1908). Calmette 
alludes to Mariadassou's successful treatment of two patients who suffered poisonous-snake bites in Karaikal Hospital in 1901 using Calmette's serum (the antivenin developed by Albert Calmette in 1894 using immune sera from vaccinated horses). Mariadassou maintained an interest in Indian medicine as well. His book le Rajeunissement par le Kayacarpam (Rejuvenation by Kayakarpam) (1938, Pondichéry) stands as an evidence in this direction. He published another book Le Jardin des Simples de l'Inde (The Simple Indian Garden), which includes notes on the pharmacognostic properties of Indian herbs. The Centre d'Information et de Documentation de l'Inde Francophonie (CIDIF) website (http:// cidif2.gol.cc/ index) lists a few other publications of Mariadassou, which could be of lateral interest to readers.

\section{Conclusion}

Geographically French Pondichéry was circumscribed by the Madras Presidency then and by the state of Tamil Nadu today. By distance, Pondichéry is about $170 \mathrm{~km}$ south of Madras and therefore any scientific development was easily accessible between Pondichéry and Madras, although these regions were managed by administrators of varying affiliations.

\subsection{Attitude towards Indian Traditional Medical Knowledge}

Especially during $17^{\text {th }}-19^{\text {th }}$ centuries, surgeons trained in western-medical practice stationed in the districts of Madras Presidency enthusiastically explored various branches of the Indian Materia Medica and medical practice, such as Ayurveda, Siddha, and Unani-Tibb. For instance, an anti-snakebite product the 'Tanjore Pills' was developed by a local vaidyan (an indigenous doctor, name unknown) in Tanjavur $\left(10^{\circ} 47^{\prime} \mathrm{N} ; 79^{\circ} 8^{\prime} \mathrm{E}\right.$, c. $180 \mathrm{~km}$ south of Pondichéry). It was compounded using white arsenic (oxide of arsenic, $\mathrm{As}_{2} \mathrm{O}_{3}$ ), mercury (Hg), black pepper (Piper nigrum, Piperaceae), nervalam (nirvãlam; Croton tiglium, Euphorbiaceae), vellinavi (vellai-navi, Aconitum ferox, Ranunculaceae), nari-visham (nari-vidam, Limonia acidissima [= Feronia elephantum], Rutaceae), and érukku (arkãSanskrit; Calotropis gigantea, Apocynaceae). The popularity of this product stormed the Madras Presidency in the later decades of the $18^{\text {th }}$ century, involving fiery discussions among the British medical doctors of that time, such as James Anderson (1738-1809) and Patrick Russell (17261805), who were stationed in Madras (Raman et al, 2014a). A Madras-based surgeon Whitelaw Ainslie (1767-1837) explored Indian plants for their medicinal value and wrote the Materia Medica of Hindoostan in 1813, a revised edition of which appeared in London as Materia Indica or Some Account of those Articles which are Employed by the Hindoos and other Eastern Nations in their Medicine, Arts, and Agriculture in 1826 (Raman et al. 2014b). Senjee Pulney Andy, the second Indian surgeon to be trained in the UK (University of St Andrews, Scotland) tested the efficacy of neem leaves $(A$. indica) in treating small pox (Raman and Raman, 2013). In short, British surgeons and Indian surgeons trained in Britain enthusiastically investigated the therapeutic potential of diverse plants of tropical southern India. Others, such as John Forbes Royle (1799-1858), too sparkle in a similar context. Such a search behaviour does not surprise, because before these British men, Johann Gerhard König (1728-1785) from Germany and Johann Peter Rottler (1749-1836) from Alsace who came to India (Tranquebar, Tarangampadi, $11^{\circ} 12^{\prime} \mathrm{N}$; $79^{\circ} 50^{\prime}$ E) as Halle Missionaries enthusiastically explored plants for their potential use in medicine (Jensen, 2005). A well-documented example of Rottler's passion for plant materials is illustrated in the paper by Carl Ludwig Willdenow of Berlin (Willdenow, 1803), which describes formally the plant specimens collected by Rottler along the Coromandel Coast and dispatched to Willdenow for determination and documentation (Raman and Prasad, 2010). William Roxburgh's discovery that 
the bark extracts of Swietenia febrifuga (Meliaceae) from southern India could treat the 'fever', which later came to be known as malaria is another milestone in early aspects of pharmacognosy of India (Roxburgh, 1812).

A similar attitude towards Indian medical knowledge may have prevailed among the early French surgeons at Pondichéry: Beautemps, Huillet, and Godinaeu. Unfortunately, no easily accessible reports highlight their interest in exploring Indian plants and in clarifying their role in treating illnesses. However, Huillet's remarks on the ancient traditional practice of 'variolation' in India point to the fact that French Surgeons too enthusiastically explored Indian medical knowledge. Mariadassou, who must have graduated from l'ÉMP, sometime in the later decades of the $19^{\text {th }}$ century (or early decades of the $20^{\text {th }}$ century?), on the contrary, demonstrates a profound commitment towards Indian medical science through his publications made on the traditional medicines and medical practice of India. His (Mariadassou, 1913) catalogue le Jardin des Simples de l'Inde (The Kitchen Garden of India) includes references to the pharmaceutical properties of herbs grown in Indian households.

\subsection{Vallarine}

Jules Lépine's work on the characterization of vallarine is remarkable in the $19^{\text {th }}$ century pharmaceutical-chemistry research in southern India. By naming the compound as vallãrine, Lépine impresses, since he derived this name from the local, vernacular (Tamil) name of H. asiatica, viz., vallãrai. Very few of the secondary metabolic compounds isolated from plants of southern India have any etymological link to their vernacular names. Isolation and characterization of vallarine shines as a singular example in that regard. The other noteworthy point is that - as much as we could find - nothing in the $19^{\text {th }}$ century southern Indian science matches Lépine's efforts made in isolating and characterizing vallarine. The only similar event that can be said is the discovery and characterization of ajmaline from Rauwolfia serpentina (Apocynaceae) in the 1930s (Siddiqui and Siddiqui, 1931, 1932,1935) and nimbidin from Azadirachta indica (Meliaceae) (Siddiqui, 1942). A neat summary of the medicinal relevance of vallarine and other active compounds in Centella asiatica (= Hydrocotyle asiatica) is available in Gohill et al. (2010).

\subsection{Appointments of Health Officers in Government Service}

In Madras, the appointments to civil (and military) assistant-surgeon positions were offered to those who had essentially had the title G.M.M.C. (Graduate of the Madras Medical College) and later M.B.C.M. (Medicinae Baccalaureus et Chirurgiae Magister, equivalent to modern day M.B.B.S.), whereas the hospital-assistant positions were offered to those who held either a Licentiate in Medicine and Surgery (L.M. \& S.) or the Licenced Medical Practitioner (L.M.P) title. Between 1835 (the year of start of the Madras Medical School, which later renamed as College) and 1855, the medical titles offered were 'Apothecaries' (Raman and Raman 2016). In contrast, the Pondichéry medical service the appointees had the M.D. (Medicinae Doctor) title and the l'ÉMP started a little later than the Madras Medical School, trained aspirants towards M. D. title only, although the number of years of training initially was three, which was later amended to five years. The Madras Medical College was established as the Madras Medical School in February 1835, while l'ÉMP was started in 1863.

\subsection{Establishment of Para-medical and Exploratory Medical Facilities}

Pondichéry health documents refer to the establishment of l'Hôpital Pondichéry in 1853. Le Ministerè de la Santé on taking full administrative charge in 1863 established a 
dedicated facility to train pharmacists and midwives in 1905 and 1912, respectively. The radiology ward was established in 1913. The Department of Pharmacy offering the Chemist \& Druggist Diploma, which later changed as Diploma in Pharmacy in Madras Medical College, started offering training to pharmacists from 1897. The Nurses Training School in Madras developed as a facility within the Government General Hospital started in 1871. In high likelihood, these Madras developments should have influenced the le Ministerè de la Santé de Pondichéry to establish these dedicated departments. An x-ray facility came up in Madras General Hospital in 1900, which was expanded into a better facility with the appointment of Thomas Barnard, who was working earlier as a radiographer at Colaba Hospital, Bombay in 1920. A new leprosarium was under consideration in Madras from 1900s, but it fructified only in 1924, with the establishment of Lady Wellington Settlement in Chengleput $\left(12^{\circ} 41^{\prime} \mathrm{N}, 79^{\circ} 58^{\prime} \mathrm{E}\right)$. After the integration of Pondichéry with the Indian Republic, health management in Pondichéry expanded in later years with the development of four hospitals, one prisonhealth service, and one leprosarium.

\section{ACKNOWLedGements}

We are grateful to Srinivasan Prasad (Institut Français de Pondichéry, Pondichéry, India) for supplying photocopies of pages from Nallam's l'Histoire de la Médecine de l'Inde Française. Prasad and Dominik Wujastyk (University of Alberta, Alberta, Canada) reviewed the pre-final draft of this mansucript. We thank Prasad and Dominik for the help.

\section{BiBLIOGRAPHY}

Aubry, P. and B.-A. Gaüzère. Histoire de la santé dans l'Océan Indien: soins, prevention, enseignement et recherche du XVII ${ }^{e}$ siècle au milieu du XXe siècle, Medicine et Santé Tropicales, 26 (2016):122-128.

Anonymous, J. Lépine's granules and syrup of Hydrocotyle asiatica for cutaneous, syphilitic and rheumatic affections, as well as for all complaints arising from organic disease, E. Brière, Paris, 1855, p. 8.

Bernoulli, R. Raimundus sebundus: prinzipien seiner anthropologie, In Philosophische Tradition im Dialog mit der Gegenwart, Springer, Heidelberg, 1985, pp. 9-28.

Bigot, A. La médecine Française à Pondichéry aux XVIII ${ }^{\mathrm{e}}$ et XIX ${ }^{\mathrm{e}}$ siècles, 91e Congrès des Sociétés Savantes (Rennes) 1 (1966):31-36.

Bonneman, B. Colonisation et pharmacie (1830-1962): une présence diversifiée de 130 ans des pharmaciens Français, Revue d'Histoire de la Pharmacie 95 (2008):311-334.

Brimnes, N. Variolation, vaccination and popular resistance in early colonial South India, Medical History 48 (2004):199-228.

Calmette, A. (translated by Austen, E.E.), Venoms, Venomous Animals, and Antivenomous Serum, Bale \& Danielson, London, 1908, p. 403.

Chippaux, C. Le service de santé de la marine, Médicines Tropicale, 40 (1980):605-630.

Dechambre A., et al., Dictionnaire Encyclopedique des Sciences Medicales, G. Masson \& P. Asselin, Paris, 100 volumes, 1864-1889.

Ducachet, H.W., Strictures on the late circular addressed to the citizens of the United States by James Smith, M.D. agent of the vaccine institution at Baltimore, The New York Medical \& Physical Journal 1 (1822):4253.

Dymock, W. The Vegetable Materia Medica of Western India, Education Society's Press, Bombay; Trübner \& Co., London, 1885, p. 1048.

Gohil, K.J., Patel, J.A., and Gajjar, A.K. Pharmacological review on Centella asiatica: a potential herbal cureall, Indian Journal of Pharmaceutical Science, 72 (2010):546-556.

Jensen, N.T. The medical skills of the Malabar doctors in Tranquebar, India, as recorded by Surgeon T. L. F. Folly, Medical History 49 (2005):489-515.

Kaeppelin, P. La Compagnie des Indes Orientales et François Martin. Étude sur l'Histoire du Commerce et des Établissements Français dans l'Inde sous Louis XIV (1664-1719), A. Challamel, Paris, 1908, p. 673.

Lépine, J. On the Hydrocotyle asiatica, The Chemist - A Monthly Journal of Chemical \& Physical Science XXV (N. S.) (1855):19-27. 
Leyel, C.F. Elixirs of Life, Samuel Weiser, New York, 1970, p. 221.

Love, R. S. The making of an Oriental: Louis XIV and the Siamese embassy of 1686, The Journal of the Siam Society 82 (1994):57-78.

Huillet, N. Contributions a la Géographie Médicale, Archives de Médicine Navale, 8 (1867a): 321-357.

Hulliet, N. Hygiène des Blancs, des Mixtes et des Indiens à Pondichéry, Geruzét, Pondichéry, 1867b, p. 272.

Husson, H.-M. Vaccination, In Dictionnaire des Sciences Médicales, Imprimérie de C.L.F., Paris, 1822, 514517.

Mariadassou, P. Le Jardin des Simples de l'Inde, Mission Press, Pondichéry, 1913, p. 274.

Massey, J., Dr J. B. J. Beaujean, Médicin en Chef de la Marine, et la Foundation de l'École de Médicine de Pondichéry (1863), Imprimérie Ipadour, Pau (Pyrénées-Atlantiques), 2007, p. 41.

Massey, J. Hôpital colonial de Pondichéry, In Les Hôpitaux Militaires des Colonies: Trois Siècles au Soutien des Forces et l'Éxpansion Coloniales, Établissement de Communication et de Production Audiovisuelle de la Défense (ECPAD), Paris, 2012, 210-213.

Nallam, V. Histoire de la Médecine de l'Inde Française, Samhita Publications, Madras, 2009, p. 318.

Oliver-Bever, B. Medicinal plants in tropical West Africa, II. Plants acting on the nervous system, Journal of Ethnopharmacology, 7 (1983):45-46.

Raman, A. Georges Guerrard-Samuel Perrottet, a forgotten Swiss"French plant collector, experimental botanist and biologist in India, Current Science, 107, (2014a):1607-1612.

Raman, A. and Prasad, S. Two-hundred year changes in the plant composition: a case study of Madras city in the Coromandel Coast, Peninsular India, International Journal of Ecology and Environmental Sciences 36 (2010):205-214.

Raman, R. and Raman A. Surgeon Senjee Pulney Andy’s trials in treating smallpox using leaves of Azadirachta indica in southern India in the 1860s, Current Science 104, (2013):1720-1722.

Raman, R. and Raman, A. A western science-based Materia Medica by Whitelaw Ainslie of the Madras-medical establishment published in 1810, Current Science, 107, (2014):909-913.

Raman, R. and Raman, A. Early days of Madras Medical College: apothecaries, National Medical Journal of India 29 (2016):98-102.
Raman, R., Raman, A., and Ram Manohar, P. The arsenic and mercury containing Tanjore pills used in treating snake bites in the $18^{\text {th }}$ century Madras presidency, Current Science 106, (2014):1759-1763.

Raman, R., Buckingham, J., and Raman A. 'The Madras leper hospital and leprosy management in $19^{\text {th }}$ century India', Current Science 103 (2012):1354-1357.

Ramaswamy, V. Gender and transcendence in Early India, In A Social History of India, Pearson Longman, Delhi, II, 5 (2009):233-250.

Rose, C. Safe, Speedy, and Certain Cure for Smallpox: with cases illustrative of its efficacy in every stage of the disease, in preventing disfigurement, \&c. \&c., John Rose, Hertford, 1863, p. 30.

Roxburgh, W. 'Swietenia febrifuga', The New England Journal of Medicine and Surgery \& the Collateral Branches of Science I (1812):199.

Siddiqui, S. and Siddiqui, R.H. Chemical examination of the roots of Rauwolfia serpintina, Journal of the Indian Chemical Society, 8 (1931):667-80.

Siddiqui, S. and Siddiqui, R.H. The alkaloids of Rauwolfia serpintina. Part I. Ajmaline series. Journal of the Indian Chemical Society, 9 (1932):1-539.

Siddiqui, S. and Siddiqui, R.H. The alkaloids of Rauwolfia serpintina. Part II. Ajmaline series, Journal of the Indian Chemical Society, 12 (1935):1-37.

Siddiqui, S. A note on isolation of three new bitter principles from the neem oil, Current Science, 11 (1942):278279.

Stephen, S.J. Caste, Catholic Christianity and the Language of Conversion Social Changes and Cultural Translation in Tamil Country; Kalpaz Publications, New Delhi, 2008, p. 402.

Thomas, M., French Colonial Legacy in Pondichery and Quebec: A Comparative Study, Ph.D. thesis, Pondicherry University, Pondicherry, 2002, http:dspace.pondiuni.edu.in/jspui/bitstream/pdy/273/ 1/T2982.pdf (accessed on 28 November 2016).

Willdenow, C. L. Botanische Bemerkungen auf der Hinund Rückreise von Trankenbar nach Madras vom Herrn Missionair Rottler zu Trankenbarmit anmerkungen von Professor C. L. Willdenow, Geâellschaft Naturforschender Freunde zu Berlin (Neue Schriften), 4 (1803):180-224.

Wujastyk, D. A pious fraud: the Indian claims for preJennerian small-pox vaccination, Studies on Indian Medical History, Motilal Banarsidas, Delhi, 2001, pp.121-154. 